International Journal of Engineering \& Technology, $7(4.38)(2018) 1222-1226$
International Journal of Engineering \& Technology
SPC
Website: www.sciencepubco.com/index.php/IJET
Research paper

\title{
Mathematical Model of Vacuum Evaporation Using Apparatus with Mechanical Water Vapor Recompression
}

\author{
L.A. Shirkin ${ }^{1 *}$, O.G. Selivanov ${ }^{1}$, T.A. Trifonova ${ }^{1}$, S.I. Roshchina ${ }^{1}$, M.E. Ilina ${ }^{1}$ \\ ${ }^{1}$ Vladimir State University, Vladimir, Russia \\ *Corresponding author E-mail: 1shirkin@yandex.ru
}

\begin{abstract}
This article presents mathematical model of evaporation of aqueous solutions of mineral salts on apparatus with mechanical recompression of water vapor and process intensification upon vacuuming. The developed mathematical model is an engineering prediction where all calculations are associated with technological flowchart of evaporator. Predictions according to the mathematical model for evaporator are exemplified for the case of $2 \%$ aqueous solution of sodium chloride evaporated to $15 \mathrm{wt} \%$ at distillation capacity of $30 \mathrm{~kg} / \mathrm{h}$. Engineering predictions were performed consecutively in 5 stages including material calculation of evaporator; estimation of evaporator temperature mode; hydrodynamic and thermal predictions; estimation of heat transfer coefficient. The developed mathematical model was applied to stationary direct flow evaporation using Mathcad Prime software. In order to perform high quality analysis and to verify adequacy of the mathematical model, 12 criteria were selected characterizing evaporation efficiency in evaporator. Advantages of the developed mathematical model were highlighted and substantiated, practical recommendations on its application were given upon efficiency estimation of vacuum evaporation with mechanical recompression of water vapor.
\end{abstract}

Keywords: Mathematical Model, Vacuum Evaporator, Mechanical Recompression of Vapor, Aqueous Solutions Of Mineral Salts, Film Evaporation, Heat Transfer Coefficient, Model Adequacy.

\section{Introduction}

Decrease in energy consumption per unit of evaporated amount is an urgent issue during development of evaporators [1], hence, improvement of energy efficiency of evaporators is of highest importance requiring for innovative approaches to evaporation. Such approaches include development of apparatuses with mechanical water vapor recompression (MVR) based on vacuum film evaporator with free draining film. Such apparatuses can be applied for salt removal and concentrating of various aqueous solutions of mineral salts [2-4], pharmaceutical organic fluids, purification of working solutions and rinsing waters of various industries. However, models for efficiency prediction and analysis of developing and operating evaporators with regard to industrial conditions are unavailable. Moreover, criteria characterizing industrial evaporation efficiency are not determined. Hence, this work is aimed at analytical estimation of evaporation efficiency at preset parameters of capacity in terms of distillate and concentration of dissolved matter in initial and final solution.

\section{Methods}

The subject matter of mathematical simulation is evaporation using pilot apparatus on the basis of shell-and-tube vacuum film evaporator with free draining film and recompression of water vapor developed at OOO BMT (Vladimir, Russia) (Fig. 1). Schematic view of the evaporator is illustrated in Fig. 2.

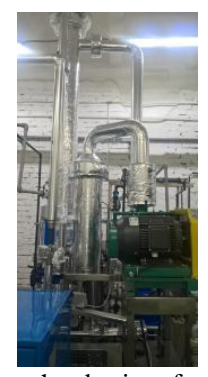

Fig. 1: Pilot apparatus on the basis of shell-and-tube vacuum film evaporator with free draining film and recompression of water vapor.

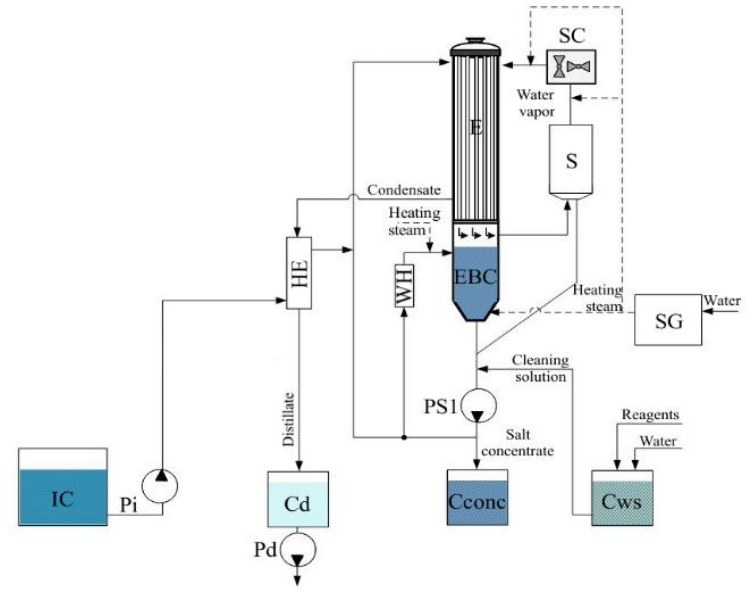

Fig. 2: Schematic view of evaporator with MVR

${ }^{\mathrm{a}} \mathbf{E}$ - film evaporator; SC - blower for steam compression; EBC evaporator boiling chamber; WH - tankless water heating; HE recuperative heat exchanger, $\mathbf{S}$ - separator; IC - initial reservoir; $\mathbf{C d}$, Cconc 
- receptacles; Cws - reservoir for washing solution; Pi, Pd, PC1 - pumps, SG - electric steam generator.

The evaporator with MVR has the following specifications: - rarefaction in the system (residual 0.7-0.8 atm pressure)

- evaporation temperature

$89-92^{\circ} \mathrm{C}$

- salt content in distillate, not less than

$100 \mathrm{mg} / \mathrm{l}$

- distillate temperature

$35-40^{\circ} \mathrm{C}$

- temperature of concentrated product, not

$95^{\circ} \mathrm{C}$

higher than

- capacity in terms of distillate (evaporated moisture)

- rated capacity, not more than

$0.03 \mathrm{~m}^{3} / \mathrm{h}$

- power consumed for evaporation, not

more than

- pressure drop provided by air blower

$7.0 \mathrm{~kW}$

$3.0 \mathrm{~kW}$

$0.3-0.35$

$(30-35 \mathrm{kPa})$

- specific energy consumption for

$40-60 \mathrm{~W} \cdot \mathrm{h} / \mathrm{l}$

evaporation

- evaporator heat exchange surface area, $1.6 \mathrm{~m}^{2}$

not more than

- number of pipes in body, $n$

$3-15$

- pipe diameter, d

13-15

$25 \times 2 \mathrm{~mm}$

- evaporator dimensions, including

evaporator $(\mathrm{H} \times \mathrm{D}$.), not more than

$1.7 \times 0.16 \mathrm{~m}$

evaporator boiling chamber $(\mathrm{H} \times \mathrm{D})$, not

more than

Evaporation in this evaporator is performed as follows: initial solution with salt content up to $40 \mathrm{~g} / \mathrm{l}$ from the reservoir IC by the pump $\mathbf{P i}$ is supplied for preheating to $60-70^{\circ} \mathrm{C}$ in the recovering heat plate exchanger HE. Heat carrier for heating of initial solution in the $\mathbf{H E}$ is steam condensate after the evaporator $\mathbf{E}$ supplied to the heat exchanger at $97-100^{\circ} \mathrm{C}$ in counter-flow to initial solution.

Heated solution after the heat exchanger $\mathbf{H E}$ is fed to the circulation pipeline: the boiling chamber EBC - the circulation pump PC1 the evaporator $\mathbf{E}$ - the boiling chamber $\mathbf{E B C}$.

Solution from the evaporator bottom part is fed by the circulation pump PC1 to flow distributor in the upper part of the evaporator $\mathbf{E}$, and then in the form of thin film is drained by internal walls of the evaporator E. Under residual pressure of 0.7-0.8 atm (rarefication from- -0.3 to -0.2 ) created by the thermocompressor (air blower) $\mathbf{S C}$ in the evaporator $\mathbf{E}$ the solution is evaporated; boiling point in the boiling chamber is $90-92^{\circ} \mathrm{C}$. The vapor liquid mixture at the output of the evaporator $\mathbf{E}$ is separated into liquid and vapor phases.

Water vapor from the evaporator $\mathbf{E}$ is fed to the separator $\mathbf{S}$ where condensed moisture is separated. The steam is sucked by the thermocompressor (air blower) SC, compressed to 1.0-1.01 atm, herewith the steam temperature increases from $89-90^{\circ} \mathrm{C}$ to $100^{\circ} \mathrm{C}$. Adiabatically compressed water vapor is fed to shell side of the evaporator $\mathbf{E}$ where it is condensed releasing the condensation heat via pipe walls to initial evaporating solution.

Water vapor condensate at $97-100^{\circ} \mathrm{C}$ is supplied to the heat exchanger $\mathbf{H E}$ for heating of initial solution and then, at $45^{\circ} \mathrm{C}$, is drained to the reservoir $\mathbf{C d}$ from which it is continuously pumped by the pump Pd. The amount of the pumped distillate $(30 \mathrm{l} / \mathrm{h})$ is measured by flow meter, its readings are used for adjustment of flow rate of initial solution by the pump Pi.

A portion of saturated salt solution $(6-10 \mathrm{~kg} / \mathrm{h})$ from the bottom part of the evaporator $\mathbf{E}$ is taken as ready product to the reservoir Cconc. The acquired amount is adjusted automatically according to the level in the bottom part of the evaporator $\mathbf{E}$. Compositions of distillate and concentrated product are controlled by electric conductance and $\mathrm{pH}$ meter of the medium.

In order to heat the solution to boiling point during startup, onset of operation mode and compensation of heat loss, the heater WH is used across which the initial solution from the boiling chamber EBC circulates.
Operation expenses of evaporator are mainly determined by energy consumption. In steady operation mode there should be the balance between energy input and output. Hence, the evaporation efficiency in such apparatuses is determined by 5 main parameters: solution boiling point upon rarefication in the system; average residence time of the solution in heating area with accounting for recirculation; power consumption for evaporation; specific energy consumptions for evaporation of $1 \mathrm{~kg}$ of distillate; heat transfer coefficient in the evaporator.

Mathematical model for evaporator has been developed for the case study of $2 \%$ solution of sodium chloride evaporated to $15 \mathrm{wt} \%$ at distillation capacity of $30 \mathrm{~kg} / \mathrm{h}$.

The predictions have been based on data for 43 variables arranged in 6 categories:

1. Evaporator design variables.

2. Specifications of evaporation.

3. Thermal and physical properties of water.

4. Thermal and physical properties of saturated water vapor.

5. Thermal and physical properties of solution.

6. Reference values, constants.

Methods and procedures applied at the stage of initial data acquisition and preparation are as follows:

1. Numerical values of coefficients in functions of thermal and physical properties of solutions are determined by means of algorithms of multivariate regression analysis based on the least square method and optimization in Mathcad 'using automatic enumeration of Interior-Point and Active-Set algorithms. Solution accuracy is controlled by coefficient of determination.

2. The functions of thermal and physical properties of solution are preset using spreadsheet without exact forms of dependencies on the basis of bilinear interpolation.

Mathematical and computer simulation is stipulated by requirements of engineering design of evaporator:

1. Material analysis of evaporator is based on the methods of material balance, theory of hydrodynamic similarity, on iterations, since the mathematical model initially considers for interrelation between solution recirculation and hydrodynamic conditions of draining film.

2. Estimation of temperature mode of evaporator is required for hydrodynamic and thermal predictions, it is based on logarithmic mean temperature difference applied for development of shell-andtube heat exchangers.

3. Hydrodynamic prediction is based on criterion equations of hydrodynamic similarity for draining film and, in addition to minimum and operation levels of linear density of water concentration, provides information about thickness, draining rate, and average residence time of solution in heating area.

4. Thermal prediction of evaporator is based on heat balance which provides information of thermal efficiency of evaporator and makes it possible to consider with sufficient details for heat loss into ambient environment both with output flows and through external surface of evaporator with accounting for applied thermal insulation.

5. Heat exchange coefficient in evaporator has been estimated using the model of cylindrical wall based on the theory of thermal similarity, it includes consecutive calculation of heat exchange coefficients using criteria of thermal similarity depending on hydrodynamic conditions of film flow of heat transfer fluids, herewith, contamination of heat transfer surfaces is taken into account and evaporation mode in the apparatus is analyzed for bubble boiling.

Technological prediction by the developed mathematical model is implemented for stationary direct flow evaporation mode in Mathcad Prime.

The model adequacy is verified by approximate methods and procedures.

\section{Results and discussion}


The proposed mathematical models of film evaporators are aimed at engineering prediction and selection of required equipment. The applied equations are based on semi-empirical criterion dependencies of hydrodynamic and thermal similarity [5-7].

The following should be determined in formulation of the simulation problem for vacuum evaporator with MVR:

- the solution recirculation rate which should be maintained in evaporator;

- the temperature distribution in flows and temperature head (driving force) in evaporator;

- the water concentration rate which should be maintained in evaporator in order to provide steady hydrodynamic mode of film draining;

- the expected heat loss with consideration for applied thermal insulation in evaporator;

- the range of heat transfer coefficient in evaporator, including accounting for contamination of heat exchange surfaces in evaporator.

On the basis of the formulation of the problem, the developed mathematical model should be comprised of engineering prediction of evaporator, since the calculations are interrelated with the facility layout. Engineering prediction in general consists of a set of calculations directly interrelated with the type, features, and operation variables of evaporation.

Mathematical formulation of the simulation problem was comprised of engineering prediction performed consecutively in 5 stages:

1) the material prediction of evaporator;

2) the estimation of evaporator temperature mode;

3) the hydrodynamic prediction;

4) the thermal prediction of evaporator;

5) the estimation of heat transfer coefficient.

At the first stage the material prediction was obtained interrelated with the flowchart of pilot evaporator (Fig. 3).

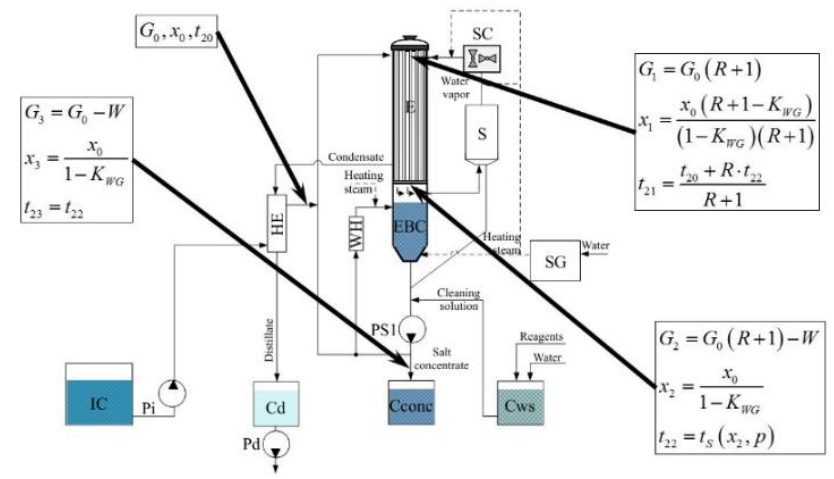

Fig. 3: Elements of material balance and flow temperatures in flowchart of evaporator with MVR

The material prediction of evaporator was based on material balance and theory of hydrodynamic similarity, herewith, the prediction was based on iterations, since the mathematical model initially considered for interrelation between solution recirculation and hydrodynamic conditions of draining film in evaporator [8-10] The elements of material balance related to the evaporator were determined as a solution of the set of equations. Concentrations of substance in flow in the upper and bottom parts of internal surface of evaporator tubes were determined by solution of the set of equations:

$\left\{\begin{array}{l}x_{1}=\frac{G_{0} x_{0}+G_{0} R x_{2}}{G_{0} R+G_{0}} \\ G_{0}(R+1) x_{1}=\left(G_{0}(R+1)-W\right) x_{2}\end{array} \Rightarrow\left\{\begin{array}{l}x_{1}=\frac{x_{0}\left(R+1-W / G_{0}\right)}{\left(1-W / G_{0}\right)(R+1)} \\ x_{2}=\frac{x_{0}}{1-W / G_{0}}\end{array}\right.\right.$

where $R$ was the coefficient of recirculation; $x_{0}$ was the initial concentration of substance in solution $(\mathrm{kg} / \mathrm{kg}) ; x_{1}, x_{2}$ were the concentrations of substances in solution in the upper and bottom part of internal surface of evaporator tubes, respectively $(\mathrm{kg} / \mathrm{kg}) ; G_{0}$ was the input flow of initial solution, $\mathrm{kg} / \mathrm{s} ; W$ was the distillate flow, $\mathrm{kg} / \mathrm{s}$.

The temperature head (driving force) $\Delta t\left({ }^{\circ} \mathrm{C}\right)$ of evaporation was determined as follows:

$$
\Delta t=\frac{\Delta t_{\max }-\Delta t_{\min }}{\ln \frac{\Delta t_{\max }}{\Delta t_{\text {min }}}}
$$

where $\Delta t_{\max }$ was the maximum temperature difference at evaporator inlet, ${ }^{\circ} \mathrm{C} ; \Delta t_{\min }$ was the minimum temperature difference at evaporator outlet, ${ }^{\circ} \mathrm{C}$

The thermal prediction of evaporator is interrelated with the flowchart (Fig. 3).

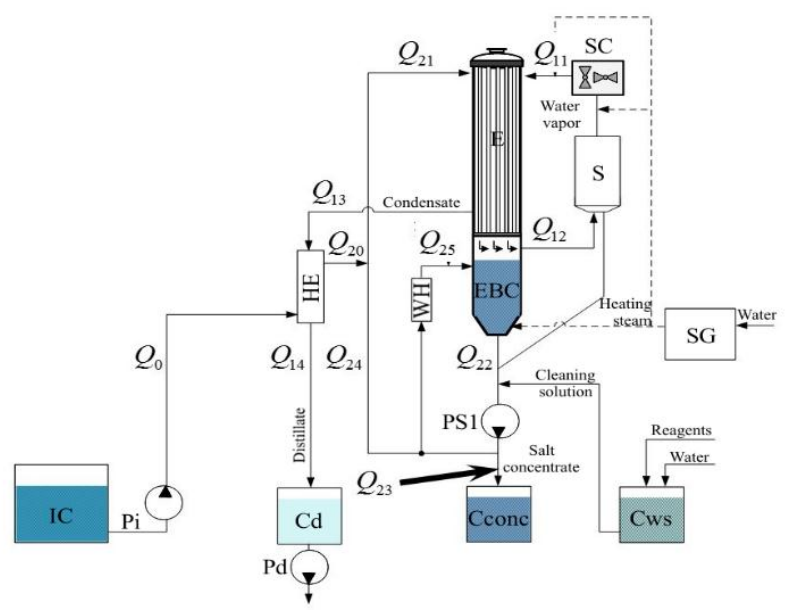

Fig. 4: Elements of heat balance in flowchart of evaporator with MVR

The thermal prediction of evaporator is based on thermal balance which provides information on thermal efficiency of evaporator and makes it possible to consider with sufficient details for heat loss into ambient environment both with output flows and through external surface of evaporator with accounting for applied thermal insulation [11].

Heat input with initial solution from the reservoir $\mathbf{I C}(\mathrm{W})$ was determined as:

$Q_{0}=G_{0} \cdot c_{S}\left(x_{0}, t_{0}\right) \cdot t_{0}$

where $t_{0}$ was the solution temperature at inlet to the recovering heat exchanger $(\mathbf{H E}),{ }^{\circ} \mathrm{C}$. Heat consumption with solution at outlet from the heat exchanger (HE) was, W:

$Q_{20}=G_{0} \cdot c_{S}\left(x_{0}, t_{20}\right) \cdot t_{20}$

where $t_{20}$ was the solution temperature at outlet from the heat exchanger, ${ }^{\circ} \mathrm{C}$.

The distillate temperature at outlet of the heat exchanger (HE) was determined by analysis of function of balance equation in the form of:

$f(t)=\left[W \cdot h_{W}\left(t_{12}, P_{0}\right)-W \cdot h_{W}\left(t, P_{0}\right)\right]-\left[G_{0} \cdot c_{S}\left(x_{0}, t_{20}\right) \cdot t_{2,0}-G_{0} \cdot c_{S}\left(x_{0}, t_{0}\right) \cdot t_{0}\right]$ where $h_{W}$ was the water enthalpy as a function of temperature and pressure, $\mathrm{J} / \mathrm{kg}$.

Solution of this function set to zero with regard to temperature gives the distillate temperature at outlet of the heat exchanger $(\mathbf{H E})$. Heat consumption with liquid distillate at outlet of the evaporator $(\mathbf{E})$ $\left(Q_{13}\right)$ and heat loss with distillate at outlet of the heat exchanger (HE) $\left(Q_{14}\right)$ were determined as follows:

$Q_{13}=W \cdot h_{W}\left(t_{12}, P_{0}\right)$

$Q_{14}=W \cdot h_{W}\left(t_{13}, P_{0}\right)$

Heat consumption with solution supplied to the upper part of the evaporator (E) was, W: $Q_{21}=G_{0} \cdot(R+1) \cdot c_{S}\left(x_{1}, t_{21}\right) \cdot t_{21}$

Heat transfer coefficient for evaporator external surface was, $\mathrm{W} /\left(\mathrm{m}^{2} \cdot \mathrm{K}\right)$ 


$$
K=\frac{1}{\frac{\delta_{\text {paint }}}{\lambda_{\text {paint }}}+\frac{\delta_{\text {ins }}}{\lambda_{\text {ins }}}}
$$

where $\delta_{\text {paint }}, \delta_{\text {ins }}$ were the thicknesses of paint and insulation, respectively, $\mathrm{m} ; \lambda_{\text {paint }}, \lambda_{\text {ins }}$ were the thermal conductance of paint and insulation, respectively, $\mathrm{W} /(\mathrm{m} \cdot \mathrm{K})$.

Heat loss through evaporator external surface was, W:

$Q_{1}=q_{1} \cdot S$

where $q_{l}$ was the specific heat flow through evaporator external surface, $\mathrm{W} /\left(\mathrm{m}^{2} \cdot \mathrm{K}\right) ; S$ was the external surface area of evaporator external, $\mathrm{m}^{2}$.

Heat consumption with evaporated solution at outlet of the boiling chamber (EBC) was determined as follows, W: $Q_{22}=\left[G_{0} \cdot(R+1)-W\right] \cdot c_{S}\left(x_{2}, t_{22}\right) \cdot t_{22}$

Heat loss with output flow of evaporated solution was, W $Q_{23}=G_{3} \cdot c_{S}\left(x_{3}, t_{23}\right) \cdot t_{23}$

Heat consumption in recirculation circuit was, W $Q_{24}=Q_{22}-Q_{23}$

Heat consumption with distillate vapors at outlet of the evaporator (E) was, W:

$Q_{12}=W \cdot h_{S W}\left(t_{22}, P\right)$

where $h_{S W}$ was the vapor enthalpy as a function of temperature and pressure, $\mathrm{J} / \mathrm{kg}$.

Heat consumption with distillate vapors after passing through the separator (S) and the gas blower was, W: $Q_{11}=W \cdot h_{S W}\left(t_{11}, P_{0}\right)$

Cumulative heat loss to ambient environment was, W: $\Delta Q=Q_{14}+Q_{23}-Q_{0}+Q_{1}$

Cumulative heat consumption in the evaporator (E) for heating and evaporation of draining film and for compensation of loss into ambient environment was, $Q=W \cdot\left[r_{S W}\left(t_{22}\right)+\left(\frac{R+1}{K_{W G}}-1\right) \cdot c_{S}\left(x_{2}, t_{22}\right) \cdot\left(t_{22}-t_{21}\right)\right]+\Delta Q$

Compensation of heat loss in the water heater $(\mathbf{W H})$ was, W: $Q_{25}=Q-\left(Q_{11}-Q_{13}\right)$

Coefficient of efficiency of the apparatus was: $\eta_{0}=\frac{Q-\Delta Q}{Q}$

Operation heat load was, W/m²: $q=\frac{Q}{F}$

Specific energy consumption for evaporation of $1 \mathrm{~kg}$ of water in steady direct flow mode was, $\mathrm{J} / \mathrm{kg}: w_{Q}=\frac{Q_{25}}{W}$

At the 5th stage the coefficient of heat transfer from heated wall to liquid film was estimated, $\mathrm{W} /\left(\mathrm{m}^{2} \cdot \mathrm{K}\right)$ :

$\alpha_{2}= \begin{cases}\frac{\operatorname{Re}_{2}^{0,2} \cdot \operatorname{Pr}_{2} \cdot \lambda_{S}\left(x_{2}, t_{\text {avg } 2}\right)}{\left(5 \cdot \operatorname{Pr}+2,9 \cdot \operatorname{Re}_{2}^{0,2} \cdot \operatorname{Pr}_{2}^{\frac{1}{3}}\right) \cdot \sqrt[3]{\frac{v_{S}\left(x_{2}, t_{\text {avg } 2}\right)^{2}}{g}}}, \quad 60<\operatorname{Re}<500 \\ \frac{0,023 \cdot \sqrt[4]{4 \cdot \operatorname{Re}_{2}} \cdot \sqrt{\operatorname{Pr}_{2}} \cdot \lambda_{S}\left(x_{2}, t_{\text {avg } 2}\right)}{\sqrt[3]{\frac{v_{S}\left(x_{2}, t_{\text {avg } 2}\right)^{2}}{g}}}, \quad \operatorname{Re}>500\end{cases}$

where $\operatorname{Pr}_{2}=\frac{c_{S}\left(x_{2}, t_{\text {avg } 2}\right) \cdot \mu_{S}\left(x_{2}, t_{\text {avg } 2}\right)}{\lambda_{S}\left(x_{2}, t_{\text {avg } 2}\right)}$

The utilization rate of ultimate heat load was determined as $w_{T}=\frac{q}{q_{T}}$ where $q_{T}=\left[0,75 \cdot A_{1}+\left(0,56 \cdot A_{1}^{2}+130 \cdot A_{2}\right)^{0,5}\right]^{2}$

$A_{1}=\alpha_{2} \cdot \sqrt{\frac{\sigma_{S}\left(x_{2}, t_{\text {avg } 2}\right) \cdot t_{22}}{\rho_{S W}\left(t_{22}, P\right) \cdot r_{S W}\left(t_{22}\right) \cdot \lambda_{S}\left(x_{2}, t_{\text {avg } 2}\right)}}$

$A_{2}= \begin{cases}\frac{\alpha_{2} \cdot \rho_{S W}\left(t_{22}, P\right) \cdot r_{S W}\left(t_{22}\right)}{c_{S}\left(x_{2}, t_{\text {avg } 2}\right) \cdot \rho_{S}\left(x_{2}, t_{\text {avg } 2}\right) \cdot \operatorname{Re}_{2}^{0,4}}, & 60<\operatorname{Re}<500 \\ \frac{2,6 \cdot \alpha_{2} \cdot \rho_{S W}\left(t_{22}, P\right) \cdot r_{S W}\left(t_{22}\right)}{c_{S}\left(x_{2}, t_{\text {avg } 2}\right) \cdot \rho_{S}\left(x_{2}, t_{\text {avg } 2}\right) \cdot \operatorname{Re}_{2}^{0,55}}, & \operatorname{Re} \geq 500\end{cases}$

where $r$ sw was the specific heat of vapor generation as a function of temperature, $\mathrm{J} / \mathrm{kg} ; t_{\text {avg }}$ was the average temperature of the second heat transfer fluid (solution) in evaporator, $\left({ }^{\circ} \mathrm{C}\right)$.

Estimated coefficient of heat transfer from condensing vapor to wall was, $\mathrm{W} /\left(\mathrm{m}^{2} \cdot \mathrm{K}\right): \alpha_{1}=2.04 \cdot \sqrt[4]{\frac{\lambda_{W}\left(t_{K}\right)^{3} \cdot \rho_{W}\left(t_{K}\right)^{2} \cdot r_{S W}\left(t_{K}\right)}{\mu_{W}\left(t_{K}\right) \cdot l \cdot\left(t_{K}-t_{\text {wall } 1}\right)}}$

where $t_{K}=t_{W}\left(P_{0}\right)$ was the condensation temperature of water vapors; $t_{\text {wall } 1}=t_{\text {avg } 2}+\frac{q}{\alpha_{2}}+\frac{q \cdot \delta_{\text {wall }}}{\lambda_{\text {wall }}}$ was the wall average temperature, ${ }^{\circ} \mathrm{C}$

Heat transfer coefficient in the evaporator (E) with noncontaminated heat exchange surfaces was, $\mathrm{W} /\left(\mathrm{m}^{2} \cdot \mathrm{K}\right)$ :

$$
K_{\max }=\frac{1}{d_{\text {avg }} \cdot\left(\frac{1}{\alpha_{1} \cdot d_{1}}+\frac{1}{2 \cdot \lambda_{\text {wall }}} \cdot\left(\frac{d_{1}}{d_{2}}\right)+\frac{1}{\alpha_{2} \cdot d_{2}}\right)}
$$

Heat transfer coefficient in the evaporator $(\mathbf{E})$ with contaminated heat exchange surfaces was, $\mathrm{W} /\left(\mathrm{m}^{2} \cdot \mathrm{K}\right)$ :

$$
K_{\max }=\frac{1}{d_{\text {avg }} \cdot\left(\frac{1}{\alpha_{1} \cdot d_{1}}+\frac{1}{2 \cdot \lambda_{\text {wall }}} \cdot\left(\frac{d_{1}}{d_{2}}\right)+\frac{1}{\alpha_{2} \cdot d_{2}}\right)+R_{1}+R_{2}}
$$

where $d_{\text {avg }}=\frac{d_{1}+d_{2}}{2}$ was the average tube diameter, m; $R_{l}$ was the thermal resistance of contaminations at external surface of tube walls upon contact with pure water vapor, $\mathrm{m}^{2} \cdot \mathrm{K} / \mathrm{W} ; R_{2}$ was the thermal resistance of contaminations at external surface of tube walls upon contact with evaporated solution, $\mathrm{m}^{2} \cdot \mathrm{K} / \mathrm{W}$.

Output data of the mathematical model were comprised of 31 parameters classified according to 4 categories: specifications and elements of evaporation material balance; properties of evaporation hydrodynamic mode; properties of evaporation thermal mode; calculated parameters determining efficiency of heat transfer and evaporation.

Adequacy of the evaporator model was verified for the case of $2 \%$ solution of sodium chloride evaporated to $15 \mathrm{wt} \%$ at distillate capacity of $30 \mathrm{~kg} / \mathrm{h}$; analysis was performed with regard to 12

\begin{tabular}{|c|c|c|c|c|}
\hline No. & Criterion & $\begin{array}{l}\text { Units of } \\
\text { measurement }\end{array}$ & $\begin{array}{l}\text { Adequacy } \\
\text { condition }\end{array}$ & $\begin{array}{l}\text { Calculations } \\
\text { according to the } \\
\text { mathematical } \\
\text { model }\end{array}$ \\
\hline 1 & $\begin{array}{l}\text { Solution boiling } \\
\text { point upon } \\
\text { rarefication in } \\
\text { system }\end{array}$ & ${ }^{\circ} \mathrm{C}$ & $<100$ & 93.4 \\
\hline 2 & $\begin{array}{l}\text { Capacity in } \\
\text { terms of initial } \\
\text { flow }\end{array}$ & $\mathrm{kg} / \mathrm{h}$ & $\leq 40$ & 34.6 \\
\hline 3 & $\begin{array}{l}\text { Capacity in } \\
\text { terms of salt } \\
\text { concentrated } \\
\text { product }\end{array}$ & $\mathrm{kg} / \mathrm{h}$ & $\leq 10$ & 4.6 \\
\hline
\end{tabular}
selected criteria characterizing evaporation efficiency (Table 1).

Table 1: Verification of adequacy of mathematical model 


\begin{tabular}{|c|c|c|c|c|}
\hline 4 & $\begin{array}{l}\text { Heat } \\
\text { consumption of } \\
\text { solution heating } \\
\text { in recovering } \\
\text { heat exchanger } \\
\end{array}$ & $\mathrm{kW}$ & $\leq 2.3$ & 2.2 \\
\hline 5 & $\begin{array}{lr}\text { Operation heat } \\
\text { load } \\
\text { evaporator }\end{array}$ & $\mathrm{kW} / \mathrm{m}^{2}$ & $\leq 40$ & 14 \\
\hline 6 & $\begin{array}{l}\text { Utilization rate } \\
\text { of ultimate heat } \\
\text { load in } \\
\text { evaporator }\end{array}$ & $\%$ & $\leq 100$ & 56.1 \\
\hline 7 & $\begin{array}{l}\text { Power } \\
\text { consumption } \\
\text { for evaporation }\end{array}$ & $\mathrm{kW}$ & $\leq 3.0$ & 1.9 \\
\hline 8 & $\begin{array}{l}\text { Specific energy } \\
\text { consumption } \\
\text { for evaporation } \\
\text { of } 1 \mathrm{~kg} \text { of water } \\
\end{array}$ & $\mathrm{kW} \cdot \mathrm{h} / \mathrm{kg}$ & $0.04-0.06$ & 0.06 \\
\hline 9 & $\begin{array}{l}\text { Temperature } \\
\text { head }\end{array}$ & ${ }^{\circ} \mathrm{C}$ & $\leq 10$ & 5.2 \\
\hline 10 & $\begin{array}{l}\text { Coefficient of } \\
\text { heat release } \\
\text { from } \\
\text { condensing } \\
\text { vapor to wall } \\
\text { (film } \\
\text { condensation of } \\
\text { water vapors) } \\
\end{array}$ & $\mathrm{W} /\left(\mathrm{m}^{2} \cdot \mathrm{K}\right)$ & $\begin{array}{l}5,000- \\
15,000\end{array}$ & 8,959 \\
\hline 11 & $\begin{array}{l}\text { Coefficient of } \\
\text { heat release } \\
\text { from heated } \\
\text { wall to fluid } \\
\text { film (boiling of } \\
\text { water and } \\
\text { aqueous } \\
\text { solutions) } \\
\end{array}$ & $\mathrm{W} /\left(\mathrm{m}^{2} \cdot \mathrm{K}\right)$ & $\begin{array}{l}1,000- \\
10,000\end{array}$ & 6,333 \\
\hline 12 & $\begin{array}{l}\text { Heat transfer } \\
\text { coefficient } \\
\text { (from } \\
\text { condensing } \\
\text { vapor to water) }\end{array}$ & $\mathrm{W} /\left(\mathrm{m}^{2} \cdot \mathrm{K}\right)$ & $800-3,500$ & $1,790-3,137$ \\
\hline
\end{tabular}

The simulation results demonstrate that the mathematical model of evaporation using shell-and-tube vacuum film evaporator with free draining film and MVR is relevant and in the presented form provides qualitative description of evaporation according to all 12 criteria, which makes it possible to apply this model for estimation of evaporation efficiency.

The obtained mathematical model has constraints: it cannot be used for analysis of concentrating of nonaqueous solutions; it does not account for solidification of substances in highly concentrated solutions; it cannot predict evaporation modes described as bubble boiling; it cannot be applied for analysis of nonstationary (unsteady) evaporation modes.

The mathematical model is characterized by productiveness, since it provides possibility to obtain reliable initial data where all thermal physical properties of water, vapor, and evaporated aqueous solution are predefined as analytical functions of temperature and pressure.

\section{Conclusion}

Evaporator efficiency is mainly determined by optimum selection of recirculation rate in film apparatus which provides: a) achievement of high concentrating rate of solutions; b) decrease in specific energy consumption for evaporation; $c$ ) decrease in heating surface incrustation. According to the simulation data, the optimum recirculation rate of sodium chloride solution is 26.18 .

The developed model can be applied in practice to study the properties and features of behavior of vacuum evaporator with MVR in stationary mode at various combinations of initial data as a tool of numerical experiments aiming at development of optimization models, and as a tool of prediction and estimation of evaporation efficiency under industrial conditions.

\section{Acknowledgments}

This work was supported by the Ministry of Education and Science of the Russian Federation (Agreement No. 75/Б/4526/15/П218 dated July 10, 2015).

\section{References}

[1] Povorov AA, Pavlova VF, Kornilova NV, Shinenkova NA (2015), Isparitel'nye apparaty $\mathrm{s}$ rekompressiei vodyanogo para energosberegayushchaya tekhnologiya i oborudovanie (ESVA) [Evaporators with water vapor recompression - power saving technology and equipment (ESVA)]. Mir gal'vaniki, 2(30), 24-27.

[2] Trifonova TA, Povorov AA, Shirkin LA, Selivanov OG, Il'ina ME (2015), Kompleksnaya tekhnologiya ochistki fil'tratsionnykh vod poligonov tverdykh bytovykh otkhodov [Integrated purification of filtration waters of domestic solid wastes landfills]. Ekologiya i promyshlennost' Rossii, 19(11), 4-9.

[3] Trifonova TA, Roschina SI, Shirkin LA, Selivanov OG, Ilina ME (2015), An integrated innovative technology for the treatment of municipal solid waste landfill leachate. Biosciences Biotechnology Research Asia, 12(3), 2481-2488.

[4] Trifonova TA, Shirkin LA, Selivanov OG, Il'ina ME, Podolets AA (2016), Otsenka effektivnosti protsessa kontsentrirovaniya vodnykh rastvorov mineral'nykh solei $\mathrm{i}$ organicheskikh sred metodom vyparivaniya $\mathrm{v}$ rotorno-plenochnom isparitele pri ochistke prirodnykh i stochnykh vod [Efficiency estimation of concentrating of aqueous solutions of mineral salts and organic mediums by evaporation in rotating film evaporator upon purification of natural and effluent waters]. Fundamental'nye issledovaniya, 9, 511-515.

[5] Lezhneva NV, Elizarov VI, Getman VV (2011), Modelirovanie i diagnostika protsessa distillyatsii v rotorno-plenochnom isparitele s sharnirno zakreplennymi lopastyami s tsel'yu povysheniya ego effektivnosti [Simulation and diagnostics of distillation in rotating film evaporator with pivotally mounted blades aiming at efficiency improvement]. Vestnik Kazanskogo tekhnologicheskogo universiteta, 18, 185-192.

[6] Ronkin VM (2012), Opredelenie ratsional'noi konstruktsii isparitel'nogo apparata s padayushchei plenkoi s tsel'yu uvelicheniya effektivnosti raboty [Determination of rational evaporator design with free draining film aiming at efficiency improvement]. Sfera. Neft' i Gaz, 2, 90-92.

[7] Tokarev SM (2013), Matematicheskoe modelirovanie termicheskoi distillyatsii vod pri plenochnom techenii v vakuume [Mathematical simulation of water thermal distillation upon film flow in vacuum]. Komp'yuternye issledovaniya i modelirovanie, 5(2), 205-211.

[8] Udyma PG, (1985) Plenochnye ispariteli [Film evaporators]. Moscow, Russia: Moscow Energy Institute.

[9] Protsessy i apparaty khimicheskikh tekhnologii [Processes and apparatuses of chemical technologies. Reference book of chemist and technologist. Part II]. (2006). St. Petersburg, Russia: NPO Professional.

[10] Petrenko VP, Ryabchuk AN (2014), Rezhimy ukhudshennoi teplootdachi $\mathrm{v}$ plenochnykh isparitel'nykh apparatakh [Degraded heat exchange in film evaporators]. Sakhar, 8, 40-47.

[11] Filippov VV (2014), Teploobmen v khimicheskoi tekhnologii. Teoriya. Osnovy proektirovaniya [Heat exchange in chemical industry. Theory. Designing backgrounds]. Samara, Russia: Samara State Technical University. 